\title{
Igreja e comunhão A colegialidade episcopal na eclesiologia de Joseph Ratzinger
}

\author{
Orientador: Mario de França Miranda \\ Doutorando: Gilcemar Hohemberger \\ Área de Concentração: Teologia Sistemático-Pastoral \\ Linha de Pesquisa: Religião e Modernidade \\ Projeto de Pesquisa: Fé e Cultura Pluri-Religiosa
}

Igreja em comunhão: a colegialidade episcopal na eclesiologia de Joseph Ratzinger, busca demonstrar que a unidade da Igreja requer a estrutura do colégio episcopal como representação das Igrejas e da sua comunhão interna, de tal modo que a colegialidade episcopal pode ser compreendida no ser da Igreja como expressão da Communio e garantia da unidade. $\mathrm{O}$ trabalho parte da eclesiologia de comunhão de Joseph Ratzinger e sua compreensão sobre o ministério episcopal para desenvolver o tema da colegialidade episcopal a partir do Concílio Vaticano II e dos desafios pastorais da Igreja hoje. A pesquisa está dividida em cinco momentos: uma introdução biográfica e teológica para situar Joseph Ratzinger no contexto eclesial do século XX; a apresentação do problema histórico da autocompreensão da Igreja e a relação histórica entre primado e colegialidade; a teologia conciliar e o desenvolvimento teológico da eclesiologia eucarística de comunhão; a demonstração dos fundamentos cristológicos e pastorais do ministério episcopal; e, por fim, a colegialidade episcopal como princípio de unidade eclesial e suas principais implicações na práxis eclesial. Ao tratar do tema da colegialidade episcopal na eclesiologia de comunhão busca-se apresentar o valor do episcopado como instrumento apto a promover uma maior comunhão entre os prelados e, consequentemente, entre as Igrejas Locais, bem como maior autonomia na obra da evangelização. Destarte, a pesquisa busca demonstrar que a unidade da Igreja requer a estrutura do colégio episcopal como representação das Igrejas, pois a grande communio, cujo papa é o primeiro, pressupõe a existência da communio ecclesiarum. Aqui reside a fecundidade pastoral tanto do primado quanto do colégio episcopal.

Palavras-chave: Jesus Cristo. Igreja. Comunhão. 